\title{
A MUSICAL FRIENDSHIP: THE CORRESPONDENCE BETWEEN MANGKUNEGORO VII AND THE ETHNOMUSICOLOGIST JAAP KUNST, 1919 TO 1940
}

\author{
Madelon Djajadiningrat and Clara Brinkgreve \\ [English translation by Aletta Stevens-Djajadiningrat]
}

A special correspondence, in the form of a substantial collection of letters written between 1919 and 1940, has been the inspiration for this chapter. The correspondents were the Javanese Prince Mangkunegoro VII and the Dutch ethnomusicologist Jaap Kunst. ${ }^{1}$ Although they came from very different worlds, they shared one common ideal: the study and preservation of the indigenous music of what was then the Dutch East Indies. This shared ideal is the reason for and essence of their sizeable correspondence, their 'meeting on paper'. But what else can these letters tell us about both the correspondents and the period in which they lived? About their life, social circle, ideals and expectations? Our grandparents' generation may not seem that long ago, but retrospective knowledge and a time difference of some 90 years make for considerable contrasts and give these letters their own character.

The date of a letter can be shocking in itself. This certainly applies to Kunst's last letter to Prince Mangkunegoro, which was dated 12 April 1940. Kunst had been back in the Netherlands since 1934. In 1940 he was hoping to make another study trip to the East, this time in his capacity as curator of the Department of Cultural Anthropology at the Colonial Institute in Amsterdam. He wrote to the Prince in Solo (present-day Surakarta) of his plans to sail for Batavia from Genoa on the Indrapoera on 15 May. He had planned a stay of six months in order to collaborate with the NIROM $^{2}$

1 Prince Mangkunegoro VII (1885-1944), also known as R.M.A. Soerjosoeparto, Prangwedono, was from 1916-1944 the ruler of the Javanese principality of Mangkunegaran. For more on his life, see Djajadiningrat-Nieuwenhuis (2006).

Jaap Kunst (1891-1960), a lawyer by training, left in 1919 for what was then the Dutch East Indies. Fascinated by the Javanese gamelan he stayed there and became a pioneer in the field of ethnomusicology. For an introduction to Kunst, his life and the new discipline he advocated, see Brinkgreve (2009), Van Roon (1995) and Proosdij-Ten Have and Van Roon (1992).

2 Nederlandsch-Indische Radio Omroep Maatschappij (Dutch East Indies Radio Broadcasting Company). 
to make recordings of 'the music of the principalities, and Sundanese, Balinese and possibly Madurese music'. After his arrival on 5 June he hoped to travel as soon as possible to Central Java. 'How I look forward to seeing all this back again!', Kunst wrote, full of expectation.

We now know that this journey would not go ahead. Even before the Indrapoera's planned date of departure, the Netherlands was occupied by the Germans and free travel was out of the question. Nor did Kunst return after the end of the Second World War in 1945. Firstly, the four-year Indonesian War of Independence made it too risky, if not impossible, to travel around and, after that, times had definitely changed. Field research into indigenous music by a Dutch musicologist was not exactly a priority in the young Republic of Indonesia. Furthermore, Kunst was not able to go back to meet his friend and supporter in musical matters, Mangkunegoro VII: the Prince had died in 1944 when the country was still under Japanese occupation. In short, with the knowledge we now possess, the letter of 12 April 1940 acquires an almost dramatic charge.

\section{9 to 1921: The Beginning}

The two correspondents had first met 20 years earlier. Kunst, a young lawyer from the Dutch province of Groningen, had left for the Dutch East Indies shortly after the end of the First World War for a variety of more or less accidental reasons. A broken engagement, restrictive family ties, as well as great dissatisfaction with his job at a dull Dutch office had made him long for change and freedom. As an enthusiastic amateur violinist he had managed to persuade the singer Kitty Roelants-de Vogel and pianist Jan Wagenaar to travel with him to the Dutch East Indies to tour the archipelago as a performing trio. From August 1919 they performed no less than 95 times in different social clubs and artistic circles, not only in Java but also in Borneo, Sumatra and Celebes (present-day Sulawesi). The journey lasted a total of eight months. Unlike his travel and trio companions, Jaap Kunst decided not to return home in May 1920. He stayed: in the Dutch East Indies he had found a passion. Javanese gamelan music, which he first heard in December 1919 at the Palace of the Sultan of Yogyakarta, had captivated and fascinated him to such an extent that he wanted to know more about it. He wanted to research this magical, enchanting music.

Bep Schrieke, Advisor for Indigenous Affairs with the Colonial Administration, had presumably asked the Sultan if he could bring the young Kunst as a guest. Thanks to a family connection with the slightly older 
and influential Schrieke, Kunst gained an ideal and natural entry into the world he wanted to explore musically. And so it was that Kunst, who at the end of 1919 was touring with his trio through the Central Javanese principalities, was also invited to a dance performance at the court of Mangkunegoro VII in Solo. Schrieke and the Prince from Solo had studied in Leiden together and stayed good friends ever since. This was the first occasion on which Kunst was the guest of the man who was to play such a crucial role in his life. On arrival in Surabaya on 28 December 1919 he wrote to the Prince about how impressed he had been by the performance: 'I do not recall ever seeing or hearing anything which, in all its different expressions, was so completely uniform, something in which music, song, gesture, colour and line were so in harmony with each other'. He only bitterly regretted that, as a Westerner, he was unable to understand the lyrics or meaning of the gestural symbolism. Kunst wrote that he had ordered a phonographic recording device in the Netherlands 'to record the overall sound of the gamelan and to help me where my hearing or the European notation might desert me'. He was already looking forward to returning to Solo after the tour and to having time for a more in-depth musical study. It is clear from this first letter that Kunst's intention of carrying out such a study had already taken shape, and so it is hardly surprising that on finishing the tour he was in no hurry to return to his home country. However, this was not Kunst's only reason for staying. By now he had met his future wife, the young teacher Katy van Wely, daughter of an ex-government administrator in Java. In order to make a living, he found himself a decent job as a lawyer with the Colonial Administration from the middle of 1920 . In addition, in his spare time he tried to find out more about the music which so intrigued him.

In September 1920, Kunst had the good fortune to experience the very best of the music and dance of the country when he was invited to the wedding of Mangkunegoro VII (image 8.1). ${ }^{3}$ To Kunst the large-scale celebrations were an overwhelming encounter with a world that was so different and, in his eyes, so magical. In a letter dated 9 September to his mother in faraway Groningen, he gave a detailed account of the festivities he had experienced 'as in a dream'. Everything was equally splendid and amazing; first of all, of course, the music: 'Gamelans everywhere as well as a European orchestra, which all play simultaneously: it is both barbaric

3 He was called Prang-wedono until 1924. To avoid confusion, we have referred to him only as Mangkunegoro. See the list of sources for an explanation. 


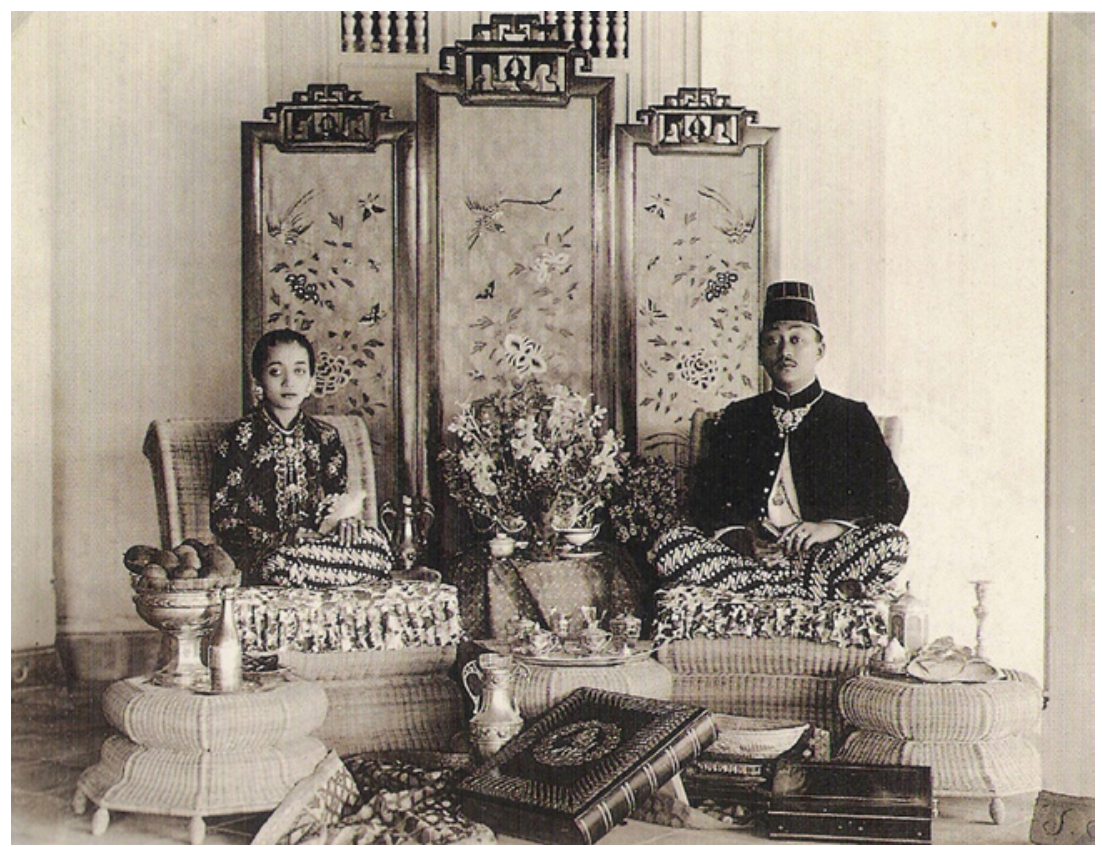

Image 8.1 Official photograph of the bridal couple, Mangkunegoro VII and Ratu Timur, 1921 (photo in collection of authors).

and magnificent and at the same time refined. [...] Some twenty gamelans mix their tones. I just don't know where I am'. Despite the hectic festivities he had been able to speak to the Prince personally and clearly convey his admiration, interest and research plans.

\section{Who were these Gentlemen?}

Who was Jaap Kunst, this newcomer in the Dutch East Indies, and who was the Javanese Mangkunegoro VII, whose shared passion for the music of the country comes across so clearly in their substantial correspondence?

Jaap Kunst, born and bred in Groningen, was 28 years old when he set foot in the Dutch East Indies. Raised in a musical family - his parents were both pianists - and a very accomplished violinist himself, he nevertheless had chosen to study law. After his studies he worked for a number of years in various offices, whilst music remained central to his life. He enjoyed making music as much and as often as possible, and during a stay on the West Frisian island of Terschelling he became interested in 


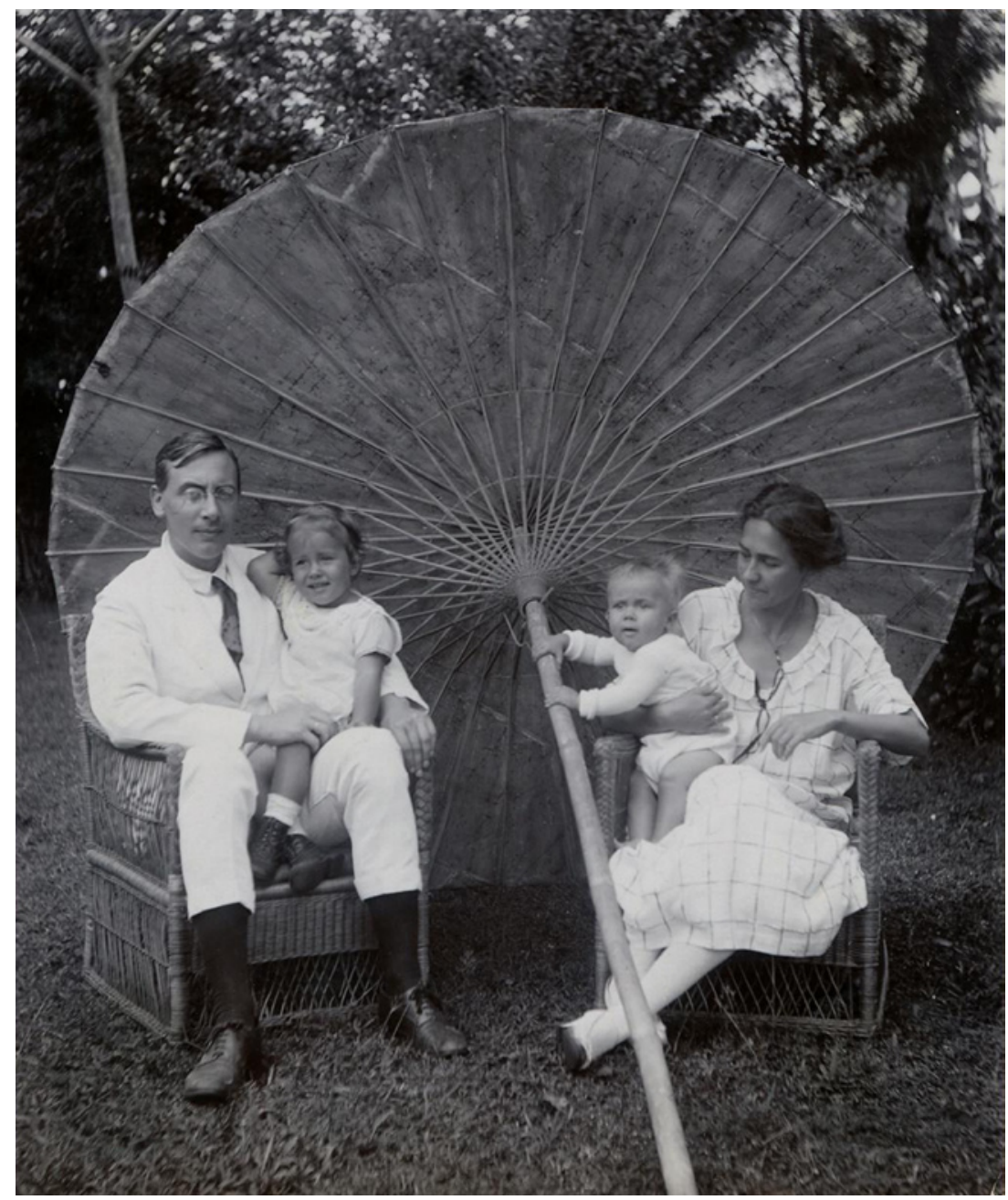

Image 8.2 Jaap Kunst and family. Bandung, 1925 (photo in collection of authors).

folk music and folklore. He carried out extensive research into the musical traditions of the island, which in 1915 resulted in the book Terschellinger volksleven (The folk life of Terschelling). Driven by this interest and with his violin under his arm, Jaap Kunst arrived in the new and exciting world of the East.

Mangkunegoro VII was the ruler of the Central Javanese principality of Mangkunegaran, which was similar in size to the Grand Duchy of Luxembourg. In 1913 Soeparto - as the Prince was called in his younger 
days - had been given the chance to go to the Netherlands to enrol in a course of Javanese Literature at the University of Leiden as a non-examination student. There he met a number of students preparing for a career in the East. At the outbreak of the First World War, Soeparto joined the Dutch Army as a reserve officer. Again he came into contact with men he was to meet later in the Dutch East Indies. In 1915, he was called back by the Dutch East Indies Administration to succeed his uncle as local ruler. In doing so, the Colonial Administration was hoping to place a man on the throne who would govern the principality as a modern ruler. $\mathrm{He}$ would not disappoint them. On the contrary, in the eyes of the colonial administrators, his reign was sometimes a little too enlightened and selfwilled. ${ }^{4}$ Whilst the Mangkunegoro may have been an idealist, he was realistic enough to be aware of it. Increasingly, he would try to shape his ideals by striving to emancipate Javanese culture, a niche that the Colonial Administration did not deny him. In the area of music he would find an ardent supporter in Jaap Kunst.

The end of the First World War brought a number of the Prince's old friends from the Netherlands to the East, including his fellow student Bep Schrieke, his friend Beijnon, the archaeologist Stutterheim and many others. In Batavia, too, cultural and intellectual life began again. Writers and painters, such as Louis Couperus, Willem Witsen and Isaac Israëls, also visited the East: Israëls made an impressive portrait of the Prince. ${ }^{5}$ Many of these visitors were warmly received at the Prince's palace. It seemed as if the Dutch East Indies was only truly discovered by the Dutch cultural and academic elite at this time.

All these birds of a different feather, full of ideals and plans, were looking for a meeting place where they could exchange their ideas on politics, religion and art without pressure from the rather meddling Dutch East Indies Government. For many, it was a source of inspiration for further collaboration. And what could be more natural than to visit their friend from the past, now Mangkunegoro VII, in order to debate together. These evenings were often enhanced by, as one of the guests expressed it, 'wondrously beautiful music and dance performances'.

4 See also Djajadiningrat-Nieuwenhuis (2006).

5 Oil on canvas, 1921, Frans Halsmuseum, Haarlem. 


\section{Striving to Preserve Culture ${ }^{6}$}

The desire to protect and preserve Javanese culture had led, in 1918, to the setting up of the Committee for the Development of Javanese Culture in preparation for a conference on Javanese culture. The conference was an unexpected success. Delegates from more than $5^{0}$ organisations, both Javanese and European, came to Solo. 1200 people attended the conference, at which the Mangkunegoro acted as Honorary President. The Java Institute, founded a year later, was the direct result of the enormous success of this conference. The Governor-General, J.P. van Limburg Stirum, became its Patron, the Mangkunegoro its Honorary President, and Dr Hoesein Djajadiningrat its President. The Institute would flourish until the Second World War. Jaap Kunst, with his interest in the Dutch East Indies, struck lucky. It meant that there was an existing platform for him to shape his musical aspirations. And he wasted no time over it. On 15 March 1921 he wrote to the Prince that he would gladly accept his invitation to the court to 'take measurements of your gamelans and notate the melodies'. In this letter, Kunst also reports that he has just examined the gamelan of the Regent of Bandung, and that as a translator the Regent had been the indispensable link between him and the exclusively Sundanese-speaking nyogos, ${ }^{7}$ as a result of which his 'tentative steps into the tropical musical landscape had gained somewhat in confidence'. For these first measurements Kunst had ensured himself of expert assistance. His good friend Jacob Clay, Professor of Experimental Physics at the newly founded Technical College in Bandung, helped him carry out the sound measurements. In a letter to the Prince, written two days after his return to Bandung, Kunst gave an account of his experiences. He wrote that he was delighted to have brought in such a 'big harvest' in two and a half days and announced that he was sending his findings in the hope that, in addition to the secretary and the nyogo, the Prince '[would] be so kind as to read through the notes on this occasion'. Kunst was polite, enthusiastic and unstoppable. With this first working visit the collaboration between the Prince and Kunst had indeed got off to a flying start, and many visits would follow.

\footnotetext{
${ }^{6}$ Parts of this section are inspired by Larson (1987), reports in the Djåwå journal, and the private correspondence of Mangkunegoro VII.

7 Nyogo refers to a gamelan player.
} 
Whilst Kunst was taking his first steps into music research on gamelans of the Mangkunegaran, preparations for a major conference of the Java Institute were in full flow. The planned dates were 17 to 19 June 1921 and the chosen location was Bandung. In addition to displays of traditional woodcarving and numerous music and dance performances, the agenda listed two themes 'for discussion'. On the morning of the second day of the conference the Necessity of History Education received much attention, whilst the third day was entirely devoted to an exchange of ideas on The Possibilities of Developing the Music of Java.

Prior to the conference, experts had been approached to write a preliminary advisory report on the said theme by answering a number of crucial questions. The experts on music included the composer Mrs S. Hofland, the musicologist J.S. Brandts Buys, ${ }^{8}$ R.T. Djojodipoero, musician at the court of Yogyakarta, the linguist J. Kats, and R.M.A. Soerjo Poetro from the House of Paku Alaman. Jaap Kunst also received such a request. It had all gone fairly quickly: he had been in the Dutch East Indies for only a year, nine months of which he had spent travelling around as a musician. Still somewhat reticent ('I have only been in the Dutch East Indies for a short while...'), Kunst nevertheless puts one or two things on paper in an extensive letter to Sam Koperberg, Secretary of the Java Institute, dated 20 November 1922. It reads like a kind of manifesto: 'Let the development of Javanese music take place exclusively with the use of, and supported by indigenous elements; let Western influence remain far removed from this art which is so very different in nature. [...] Western infection is threatening to destroy the indigenous music'. Kunst emphasises the enormous importance of support 'which makes good training of native musicians and good gamelan performances possible'. In this respect, he expected much from 'artistic and developed elements in the native population, from local rulers and priayis'. ${ }^{9}$ He was thinking, undoubtedly, of the luminous example of the ruler from Solo, the Mangkunegoro. Moreover, he emphasised the urgency of studying and recording old compositions, and indicated that he knew who would be able to do this. 'It just so happens that there are at present a number of musicologically competent

8 J.S. Brandts Buys (1879-1939), descendent of a musical family, left for Batavia in 1919 as correspondent for the $N R C$ newspaper. He published articles on the music of Madura in $D j a ̊$ å , the journal of the Java Institute. After an initially friendly working relationship with Kunst, the relationship was disrupted by the rivalry for the post of government musicologist. He died in Yogyakarta.

9 Priayi: man of aristocratic status. 
people in Java, who would like nothing better than to be able to devote their best efforts and time to the study of indigenous music'. Apart from himself, he was also alluding to the musicologist Brandts Buys, who had arrived in the Dutch East Indies one year before him and who, like Kunst, was fascinated by the music of the country.

It is clear from the report on the conference discussion on music - published in the journal Djåwå, the publication of the Java Institute - that the delegates shared a general concern about the survival of indigenous music in the country. Although one or two people were still hopeful of a kind of fruitful synthesis of Eastern and Western music, the majority were in favour of nurturing, stimulating and studying the indigenous music and of scrupulously avoiding any Western influence. In conclusion, a number of recommendations were made with the following main points:

- to promote Javanese music in education under native guidance;

- to make an academic study of the music and instruments;

- to promote the development of an appropriate and usable notation (Djåwå 1921: 300).

For the latter, a prize draw had been organised, which was entrusted to a committee under the chairmanship of the musicologist and researcher Brandts Buys.

\section{1 to 1924: Intensifying the Contact}

The contact between the Mangkunegoro and Kunst, which had been firmly established before the Bandung conference where both had been prominent, developed at a rapid pace. Especially between 1921 and 1923 dozens of letters are sent to and fro. The main subject is, and will remain, music research - in particular that of the gamelan music at the princely courts of Central Java - and the tone remains extremely polite and somewhat distant, although now and again there is mention of private matters.

In a letter dated 27 July 1921, Kunst informs the Prince of his plans to go to Bali for two weeks in October of that year. He asks him for possible useful introductions, because, as he writes: 'I would, of course, also like to make use of this journey to become acquainted with the Balinese gamelan'. En route he wanted to pay another visit to Solo and 'ask your nyogos some more questions'. The Prince's reply - written within a week: 2 August - contains all kinds of accurate information about gamelans and 
contacts in Bali, and once again the reassurance 'of all assistance from our side in your very important research'. Kunst's letter in reply (7 September), which provides a further report on the preparations for the journey to Bali, reveals that Kunst is about to get married. He writes to the Prince: 'We are looking forward very much to our journey, which at the same time is our honeymoon. [...] We propose to visit you on our way back to Bandung. [...] Would this be convenient for you?'

This is how the first working visit by Kunst and his wife to the Solo court is initiated: Katy will assist her husband in his research from the first day of their marriage. Even before the wedding on 4 October and their subsequent departure to Bali, the Prince responds with a short letter containing very joyful family news:

23 September 1921.

Dear Mr Jaap Kunst,

First of all I bring you the news that Ratoe Timoer has given birth to a daughter on Saturday the 17th of this month. If you were to visit us on 22 October it will be the selapanan (35th day) of the birth of our child and we will hold a wayang kulit performance which will last all night. [...] It will be our great pleasure to meet your young bride then.

With kind regards,

Yours sincerely, Prang-wedono

The letter of congratulations is sent to Solo by return of post and the invitation to the wayang kulit ${ }^{10}$ is gratefully accepted. But Kunst would not be Kunst if the largest part of this letter (26 September) was not devoted to research matters. Having only just returned to Bandung from his honeymoon and study trip to Bali - the account of which would appear in book form as De toonkunst van Bali (The music of Bali, with C.J.A. Kunst-van Wely,) in 1925 - culminating in both a festive and a very productive visit to Solo, Kunst thinks back with gratitude to those fruitful days. 'How wonderful it is to work when one feels assisted and supported from all sides', he writes on 25 October to the court in Solo. He includes a long list of questions which he hopes to be answered in connection with his dissertation Over de Javaansche toongeslachten slendro en pelog (On the Javanese tuning systems, Slendro and Pelog), on which Kunst is working tirelessly. After the information received has been incorporated, the Prince is asked

10 Wayang kulit: puppet theatre where the shadows of the flat puppets are visible on a screen. 


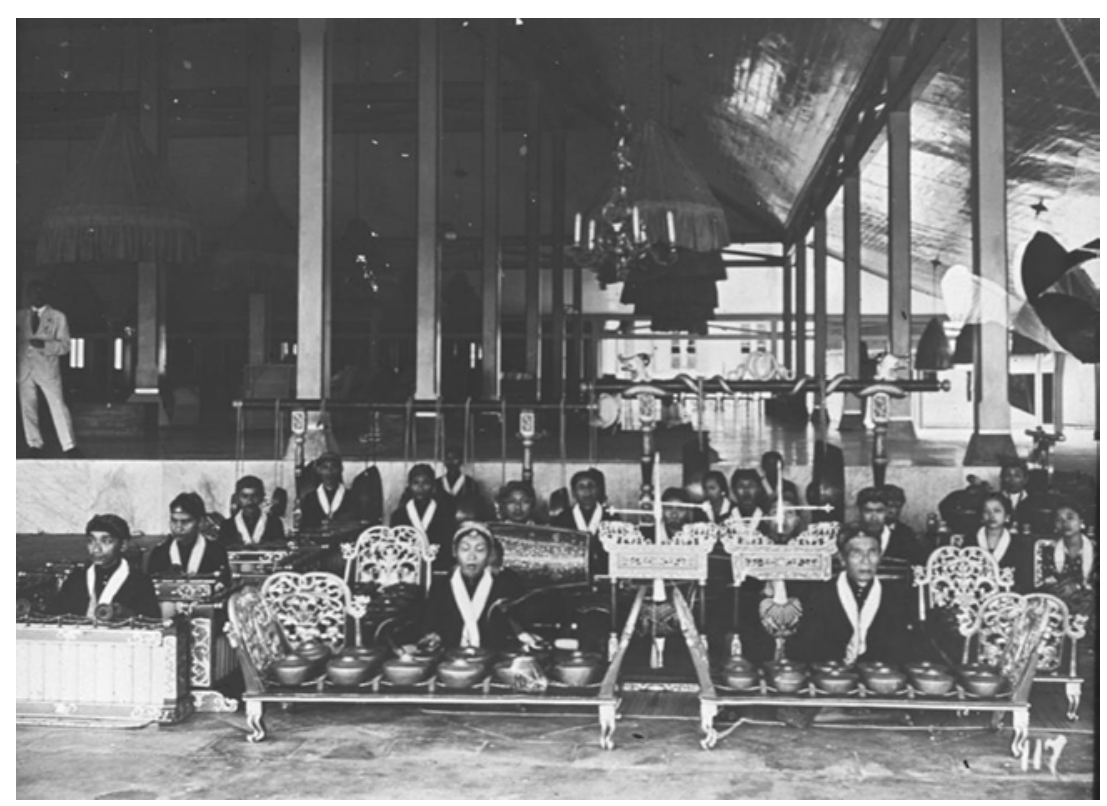

Image 8.3 Gamelan orchestra in front of the pendopo of the Astana Mangkunegaran, 1923 (photo in collection of authors).

to read it again, provide advice, and so on. There is frequent contact by letter and the exchange is detailed and full of content. As soon as Kunst is able to take leave, he arranges another working visit to Solo. On Sunday 16 April 1922, for example, Kunst intends to take the well-known photographer Adam with him to Solo, he writes a week in advance. The tone of the letter is remarkably informal, almost bold: 'I understand from Dr Schrieke that you also have some excavated Hindu-Javanese wilahan ${ }^{11}$ in your possession. Would it be possible to quickly measure the pitch of those, too?' Gradually, Kunst begins to see the gaps in his knowledge: 'A great many', he writes in the same letter, to which he adds that during the research, for which the available time is always limited, his wife's support has been 'better than any I could have wished for'.

Shortly afterwards (5 May), Kunst sent a comprehensive overview of different gamelan inventories drawn up by himself, thanked the Prince once again for all his hospitality and assistance, and expressed his hope

11 Hindu-Javanese wilahan are keys; sometimes the term also means variation or manner of playing those keys. 
that he would be able to receive him and his wife as his guests in Bandung. Whilst it may not have been a house visit, when the princely couple come to Bandung later that year, a meeting takes place nonetheless. Kunst and his wife are also on the list of invited guests for official festivities at the Solo court, but they do not always manage to attend. An evening party on 18 December 1922, for example, had to be cancelled because Kunst had no leave remaining. He had considered going on his own, since earlier notes were still raising so many questions and, he writes, he was also ready to 'hear some more beautiful gamelan music and breathe in the Central Javanese air'. Another visit to Solo was not in the offing for the time being. 'Unfortunately' he was tied to Bandung because of his job, but domestic duties and a lack of financial resources also played their part; the purchase of an instrument for their own collection regularly caused a deficit in their limited household budget. However, he did have time to write and work through the material, as he reports to his princely friend on 16 April 1923. A letter from Kunst dated two months later (9 June) shows that a personal visit from the Prince and his wife to the Kunst family residence in Bandung had taken place by then. Katy, too, mentions in her daughter's baby book that this was a very special and honourable visit: '12 June 1923. [...] It was a funny and extremely nice visit. Sjuwke sat on Ratoe Timoer's lap for ages and fiddled about with the beautiful glistening gems on her rings and bracelets'.

Later that year, they made plans to visit Solo again. At the request of Sam Koperberg of the Java Institute, Kunst, together with Katy, was working on a 'simple educational booklet on musical instruments' for which he wanted to take some pictures at the Solo court. 'And may we appeal once again to your hospitality during those four days in Solo?', Kunst writes on 6 August 1923. Evidently, this had become a habit by now. Kunst also expresses the hope that during his visit the first meeting of the musical prize draw committee will take place. He does not hide from the Prince his irritation with the committee's Chairman, J.S. Brandts Buys, 'who is not forwarding the entries'. Eventually, Katy has to forego her visit, much to her regret. The fact that she remains closely involved, however, is clear from a letter on his return from Solo (25 September): 'The photographs taken of the instruments of the Kj. Kanjoet Mesem ${ }^{12}$ have all, without exception, come out well. [...] My wife is busy making prints. She will shortly send you a copy of each photo.'

12 Kanjeng Kyahi Kanjoet Mesem, the Mangkunegaran's most famous gamelan. 
A month later (20 October), Kunst unveils a plan to gather the necessary information with fewer time- and money-consuming trips to Solo. He proposes to take in an experienced and intelligent nyogo for a few weeks at his house, but wonders how to deal with his social status: 'For example, will he want to eat with us, or on his own, or with the servants, on the chair or on a mat; does he want a bed or a baleh-baleh: ${ }^{3}$ in short, how does he want to be treated and how will he feel most at ease?' The nyogo need not be afraid of being questioned for too long, Kunst wrote, because he himself would not be home from the Department until after two o'clock.

The Prince, however, disliked the idea: the costs would not be offset by the results, especially since nyogos 'are largely known for being very whimsical and volatile', he wrote on 22 December. He advised Kunst to gather his information in Solo and to try and stay a little longer next time, as there was much assistance available, 'for which I also make myself personally available to you'. Kunst took the advice and on 28 December wrote that he agreed it would be better for him to come to Solo and listen as much as possible. Moreover, he made it known, '[we are] expecting a reduction in income and an addition to the family'.

The confidentiality between the correspondents is also evident from the remainder of this letter, including the frank grumbling about the slow dealings of the prize draw committee - the Chairman in particular was criticized again - and Kunst's outspoken and harsh opinion about the work of the composer and musicologist P. Seelig. As a safety measure he added: 'Please regard these remarks as intended only for you'.

The extent to which the Prince trusted Kunst in musical matters is clear from a letter dated 11 January 1924. When Koperberg and Kats wanted to visit the Prince in Solo in connection with 'the judging of the entries for the Javanese music prize draw', he enquired whether it would be possible for Kunst to be present at this discussion. Kunst's reply (14 January) shows that he was not keen on this, because he would not be able to combine this visit with useful research. The Prince replied on 29 January that he understood his reasoning and hoped that Kunst would soon be able to take leave in order to carry out further research into the patets ${ }^{14}$

13 Baleh-baleh: wooden or bamboo resting couch.

14 Patet means mode. Within each laras (tuning/scale, i.e. slendro or pelog) there are three patets. This does not apply specifically to the gender (instrument). Possibly, it concerns pathetan: mode-establishing musical pieces which are played on gender. 
on the gender. ${ }^{15}$ 'The time shortly before or after the festivities to celebrate my birthday and my change of name will possibly be the most suitable', he writes.

Preparations for the Prince's elevation to Mangkunegoro had been ongoing for some time. On 26 July 1924 Kunst, in the throes of writing an article on the gamelans of the Mangkunegaran, requested further information; he very much wanted a speedy reply to his questions: 'Would it be possible before 12 August?' Apparently, the relationship between the two allowed this kind of impatience, as on 7 August the Prince sent a comprehensive reply.

\section{Extra Issue of Djåwå, 4 September 1924}

For a number of friends and contacts at the Java Institute, the Prince's elevation to Mangkunegoro was an occasion to issue a special edition of the journal Djåwå in 1924. The list of contributors gives an impression of the diversity of the participants, such as the poet Noto Soeroto, ${ }^{16}$ Dr Hoesein Djajadiningrat, the critical government administrator A. Mühlenfeld, Prince A. Hadiwidjojo, son of the Susuhunan, Chairman of the Committee for Popular Literature Dr A. Rinkes, R.M. Gondowinoto from the House of Paku Alaman, the kraton physician R.T. Wediodiningrat, the archaeologist Dr Martha A. Musses, the Secretary of the Java Institute Sam Koperberg, the linguist J. Kats, the missionary H. Kraemer, his friend and Advisor for Indigenous Affairs Dr B.J.O. Schrieke, the architects T. Karsten and H. Maclaine Pont, Professor B. ter Haar, the Regent R.A.A.A. Djajadiningrat and, last but not least, Jaap Kunst. Kunst's article, illustrated with photos of instruments and players, takes up some six pages and concludes with an overview of De stemming van eenige Mangkoe Nagarasche gamelans, weergegeven in absolute trillingsgetallen en in "cents" (The Tuning of Some Mangku Nagaran Gamelans, Represented in Absolute Vibration Numbers and in 'Cents').17

Kunst is of the opinion that Java is undergoing an accelerated developmental process, resulting in 'an imbalance taking hold of the mind'. He expresses his great irritation with and concern about the penetration of Western kitsch, which shows 'how much the Javanese people in this time

\footnotetext{
15 Gender: wooden or bamboo musical instrument with copper keys.

16 On Noto Soeroto, see Djajadiningrat-Nieuwenhuis (1993).

17 Cents: a measure for tonal intervals. Jaap Kunst himself did not play, but he was very keen to take tonal measurements: determining the exact pitch - absolute vibration numbers - of all keys/gongs of the Mangkunegaran gamelans.
} 
of transition need the level-headed and loving guidance of the best from their midst in the struggle for the preservation of culture'. It is no surprise that he eventually points to the Mangkunegoro as the great example and as just the person to help revive Javanese literature, music, dance and wayang, and to promote the research 'into the essence, origin and development of the arts'.

The special issue of Djåwå provides a good overview of the discourse during the inter-war period in the Dutch East Indies, a debate that took place amongst the artists and intellectuals where Jaap Kunst, with his ideas and aspirations, felt completely at home. Back in Bandung after the elevation festivities, he excitedly writes to the Mangkunegoro: 'The days I spent in Solo were unforgettable. I have thoroughly enjoyed it. Perhaps most of all of the wireng dances ${ }^{18}$ on the third night. I am very grateful to you for allowing me to experience all this' (10 September 1924).

\section{5-1928: Intermezzo}

There now followed some years of sporadic contact between the two correspondents, partly due to the Kunst family's long period of leave. Only a few letters were exchanged. Naturally, Kunst sent a copy of the book De toonkunst van Bali, hot off the press on 1 May 1925, for which he and his wife had collected the material in 1921, and which was now published in both their names. The Mangkunegoro congratulated them warmly with this 'substantial and important work': 'Your aim of stirring interest in a hitherto practically unknown area of study [...] may certainly be considered a success' (9 May).

Kunst regarded it as less of a problem that there was no immediate prospect of an English or French edition, which the Mangkunegoro had so been hoping for. It presented an opportunity to incorporate any further comments on the Dutch edition later. Moreover, it made it possible to add the new findings collected by the painter and musician Walter Spies ${ }^{19}$ during his travels through Bali.

There is only one letter from the year 1926. This is Kunst's reply to the Mangkunegoro's invitation for himself and his wife to attend the celebrations for the copper jubilee of his years in office. Much to his regret, Kunst

18 Wireng dances: war dances for duets (two men or two women), often with weapons such as keris, bow and arrow or dagger.

19 Walter Spies (1895-1942) was a Russian-born German painter, choreographer, writer, photographer and patron. In 1923 he arrived in Java, where he lived first in Yogyakarta and in 1927 moved to Ubud, Bali. 
had to decline: his job did not permit him to go, as his superior was on leave. In the following year, at the end of April 1927, it was time for the Kunst family's long leave.

\section{8-1929: The Appointment to Government Musicologist}

At the beginning of March 1928, when Kunst had only just returned from his long period of leave in Europe, contact with the Mangkunegoro in Solo was renewed. Subject and tone remained the same. In a letter dated 6 March the Mangkunegoro thanks Kunst for sending one of his publications, and tells him about an interesting visit to the court by an American musician, Van Eighem. According to the Mangkunegoro, the latter took the trouble 'to notate old and new melodies with which he plans to deliver a composition suitable for European instruments. At the Mangkunegaran he set to music an old gamelan melody, unsuccessfully I believe, as he was interrupted too many times by Mr Brandts Buys's comments and remarks'. Clearly, the same irritations had remained. At the very end of the letter is a postscript containing a not unimportant message, an urgent request, in fact: 'When are you coming to Solo? I would like to hear your impressions of the situation in Europe'. Kunst replies by return of post (9 March) to say that he is coming over that very month. During that meeting, a topic which would undoubtedly have been discussed at length was the possible post of government musicologist. This matter would dominate and divide the musical world of the Dutch East Indies for a good while yet, and Kunst, being one of the candidates, had an important friend and supporter in the Mangkunegoro.

In this respect, Kunst had made good use of his period of leave. Wherever possible, he had drawn attention to the importance of music research in the archipelago. He had tried to convince everyone, up to the highest level, that research into indigenous music was too important to leave to private initiative, and that it was high time that the Colonial Administration accepted its responsibility in this matter and appointed a musicologist to carry out systematic research. This fervent plea seemed to have struck a sympathetic chord. Influential scholars, such as the cultural historian Johan Huizinga, ${ }^{20}$ became convinced of the importance of the

20 The historian Johan Huizinga $(1872-1945)$ is considered to be the founder of Dutch cultural history. His most well-known work is Herfsttij der Middeleeuwen (The waning of the Middle Ages) (1919). 
matter. Moreover, Kunst managed to persuade him and others that he himself was just the man for the job. But Kunst was not the only one: J. Brandts Buys was also in the race and this rival had supporters within the Java Institute.

Whilst the decision to appoint a musicologist in government service was taking its time, the Mangkunegoro encouraged Kunst at regular intervals: 'How is the music research going? So far I have not heard anything about the government's decision. I am still hoping that you will be appointed' (31 October 1928).

But there was hope in terms of the music research. In a letter of 2 September 1929, Kunst writes with relief that the decision to appoint a government musicologist had finally been taken: "There [is] a good chance that I will enjoy complete freedom of movement in a couple of months. If that should become a reality, I have the feeling that I will have almost nothing more to wish for!' The question as to who would get the job remained uncertain, and therefore exciting, for a while longer. Due to the suspense surrounding the appointment, Kunst was even absent at the conference held in Solo at the end of December 1929 on the occasion of the tenth anniversary of the Java Institute. He told his princely friend why he and Katy had decided not to come: 'There are a number of figures in Solo who have become extremely unsympathetic to me, whom we would inevitably keep having to face at the conference. I would rather avoid this irritation' (30 November 1929). A week after the conference the decision about the appointment was finally made: Kunst was the successful candidate. One of the first to be informed by him was the Mangkunegoro (9 January 1930):

I have just received the news that I have been appointed as civil servant for the systematic research into Indonesian music. Such a relief. Now those two years of unpleasantries have not been in vain. I have to leave it at these few words, as it is already very late. But I did not want to neglect to inform you immediately, as you have always shown such interest. With kind regards, also to Ratoe Timoer and also from my wife,

Yours affectionately, J. Kunst

The Mangkunegoro congratulates Kunst enthusiastically on his appointment: 'Finally, then, the hope of many has been fulfilled', he writes on 14 January, and concludes the letter with a cordial question: 'May I expect you both in Solo shortly?' But travelling to Solo would hardly be possible. 


\section{0-1931: Research in the Outlying Districts}

After the Kunst family had moved to a larger dwelling, where the by now substantial collection of musical instruments could be housed, Kunst left on 11 March 1930 on his first big expedition as government musicologist. His travel destination and area of research was the island of Nias. Meticulously, Kunst kept the Mangkunegoro informed on a variety of matters. Thus, he let him know on 12 February that he wanted to come to Solo with Katy as soon as possible after his return: 'I hope I will then be able to tell you much about Nias and possibly also show you one or two things: presumably, the painter and drawer Rudolf Bonnet ${ }^{21}$ will come with me.' He also told him that he would be taking a Kodak camera to record dances with song. Finally, he wrote that he hoped to be able to receive the princely couple at the Music Archive as soon as it was in an orderly state. Due to lack of time, the latter would not be achieved for the time being, but the exchange by post continued. Thus, the Prince enquired in a letter of 23 May when Kunst was intending to continue with the research into the music of the principalities, now that in his new job he had started research in the outlying districts. In his reply of 26 May Kunst defends his policy by pointing out the vitality and blossoming of Javanese music compared to the sad state of affairs in the outlying districts: 'In North Nias there was hardly anything left of the old culture; a collection of Christian psalmsinging little citizens, colourless and unimportant, is the result of 70 years of government interference and missionary zeal' (see also the chapter by Persoon in this volume). In South Nias the old culture and music would vanish within ten years as a result of 'contact with Western civilisation and closer contact with unadulterated Malaysian elements'. 'And this is how it is everywhere', he writes pessimistically: 'I should have ten bodies'. As government musicologist, Kunst travelled to and researched all kinds of islands and regions of the archipelago. After Nias came Flores, and the following year Bencoolen in Sumatra. The yield was enormous: musical instruments, sound recordings on wax cylinders, film recordings of dances, and series of photographs. Kunst kept his princely friend informed by letter as much as possible and visited him once or twice, usually en route. In between the travelling and working, Kunst had begun to write an extensive treatise on Javanese music. He was keen to show the Mangkunegoro

21 Rudolf Bonnet (1895-1978) worked closely with the German painter Walter Spies. In 1929 he settled in Bali, where he began to draw and paint. 
his gratitude for all the support he had been given and asked him in a letter if he could dedicate this 'small work' to him, as it was through his personal assistance, criticism and encouragement that he had 'more than anyone made it possible to compile this small work' (26 September 1931).

\section{2-1933: The Crisis Years}

By now the tide had turned. The news that the post of government musicologist would be cut on 1 January 1932 did not exactly come as a surprise after all, the financial world had been in crisis since the Great Crash of 1929 - but it made it no less painful for those involved. As soon as Kunst heard that it was on the cards, he informed the Mangkunegoro (8 November 1931). His reaction was one of empathy and support: 'Your letter [...] that you too have been hit by the cuts [...] hurt me deeply' (1 December). The Mangkunegoro encourages him by stressing once more the importance of his musicological work and by expressing the hope that 'when times are better they will restore your post'.

The post may have been abolished, but the work with which the two men were so involved in, and that had brought them so close together the protection and study of indigenous music - had certainly not disappeared from their sphere of attention or from their lives. Kunst, who had to move to Batavia in connection with his new job as Secretary to the Head of the Department of Education, Bep Schrieke, writes to the Mangkunegoro (16 December) that he still has a month to complete his musicological work: 'So I have the opportunity to come to Solo one more time. I'm looking forward to it very much: there are still so many things which I would like to hear or ask'.

How important the collaboration with the Mangkunegoro - and certainly this visit - was to Kunst is evident from a letter dating from this period, addressed to his parents in the Netherlands (9 December):

Next month I am going to Solo once more for 14 days, to Mangku Negoro, who has offered to have his gamelans played for me every morning, so that I can test everything against reality which I recount in the book. The way in which I am being assisted in this work from the Javanese side really is exceptional.

After this, the two correspondents would see each other in person only a few more times, but the flow of letters would continue for much longer.

It was thanks to Schrieke that, in his new job, Kunst was initially able to carry out a great deal more musicological research. As Director of 
Education, Schrieke travelled around the archipelago in order to see where it was possible to make education cuts in these stringent times, and Kunst accompanying him as his Secretary received every cooperation to research the local music and dance. In this period of travelling and double duties Kunst found little time to correspond, but contact with the Mangkunegoro certainly remained alive and important. Kunst apologises for still not having brought over his manuscript on Javanese music: he is 'in a manner of speaking, working on it day and night'. Should the Prince be coming to Batavia around Christmas, he would be able to see everything for himself. For the time being, it would not be possible for Kunst to visit Solo: 'It is a pity that the Department demands so much of my good time and zest for work' (16 December 1932).

\section{4-1935: Music of Java}

The lack of available time only seemed to have increased the desire to write. In no other year did the two men correspond as intensively as in 1933: some 40 letters were exchanged. The main subject of most of these letters was the large work on Javanese music for which the Prince was constantly receiving new versions and additions, and on which he subsequently commented. There were several reasons why there was much pressure to complete this project, which was largely considered to be a joint effort. In the middle of 1934 Kunst was to go on a long period of leave, and he wanted to conclude this large piece of work by then. The Prince, from his side, was fervently hoping that the publication of the book would coincide with the celebrations for his 5 oth birthday on 19 May 1934, as he wrote on 5 January of that year.

It was not to be. The Kunst family went on early leave on 7 March, especially because his great help and support, Katy, was completely exhausted. 'My wife and children are in great need of their European leave', and he himself considered coming back on his own in November (8 January 1934). He doubted whether the book would be ready for the date that the Prince was so wishing for, but once in the Netherlands he would be able to chase the publishers, Nijhoff, daily to make haste with the matter. Just before his departure, however, he informs the Mangkunegoro in a PS to his letter of 23 February: 'Book not ready for middle of ' 34 '.

Kunst would not return. He announced this as early as the beginning of 1935. In addition to private reasons, he mentions that there 'won't be any money anyway for further research in the outlying districts'. However, 
Kunst informs him that not going back certainly does not mean the end of his study of Indonesian music: 'Of course, the music study will continue [...]. I have more material with me than I could possibly work through for the rest of my life' (17 January 1935). The Mangkunegoro's reply cannot conceal his disappointment: 'but one must not be so egoistic as to hope for your return. We wish you and your family all the best, also that you will soon find the post in Holland that you wish for' (16 February).

After a difficult initial period, on 1 January 1936 Kunst found a job to which he was infinitely suited: Curator at the Department of Cultural Anthropology at the Colonial Institute in Amsterdam. The Prince sends his warmest congratulations: 'We were delighted by your news that, thanks to your appointment, your concerns about the future have been wiped away' (13 January).

\section{6-1937: The Mangkunegoro Travels to the Netherlands}

It is likely that around this time the Prince began making plans to go to the Netherlands. Rumours about the marriage between Princess Juliana and Prince Bernard had been circulating for some time. It would be convenient if he could combine a visit to his old friends with his attendance at the wedding. The Council of the Indies agreed and an official invitation was arranged from the Netherlands.

Naturally, the Mangkunegoro hoped that this journey would put his principality on the map not only politically, but also culturally. A splendid way to achieve this would be a radio broadcast of his gamelan orchestra directly from Solo, as wells as a Srimpi dance ${ }^{22}$ performed by his daughter Siti on the occasion of the wedding. The broadcast had become technically possible a year ago. In a letter of January 1935 Kunst had reacted enthusiastically to the news that 'Solo now broadcasts gamelan music with a bigger and better transmitter'. When the Prince and his family arrived in the Netherlands in December 1936 collaboration between the NIROM and Radio Kootwijk had ensured that everything was arranged to enable such a broadcast.

22 The Srimpi dance normally features four female dancers. Javanese folk etymology has it that Sri means king or queen and impi means longing, dream or wish. This dance acts out 'the longing to live in honesty and peace'. 
On 17 December, the dress rehearsal took place in the presence of 40 guests. At a quarter past four in the afternoon the connection was established. Gusti Siti carried out her dance. The connection faltered only once. The names of the guests are not known, but it is highly likely that Kunst was present. To the Prince and to Kunst as musicologist the fact that this had been achieved and that it would be repeated at the palace of Queen Wilhelmina was a reward for their long and intensive collaboration. And it did not go unnoticed: the press was enthusiastic.

A week later, the Mangkunegoro and the Ratoe Timoer invited Jaap and Katy Kunst to lunch at Wassenaar Castle. They will undoubtedly have talked about the broadcasting experiment, since the dance performance for the Royal Family was yet to take place.

Just before the Prince and his family left Holland, Katy sent them a goodbye letter with good wishes, saying with how much pleasure she and her husband looked back on the lunch at Wassenaar. The Prince's reply ends with words that express his feelings of friendship: 'I sincerely hope that one day we may meet again at the Mangkunegaran. How I would rejoice at that and many others with me, both because of your presence and for the sake of Javanese music'.

\section{Conclusion}

The Prince must have been pleasantly surprised when, some years later, in the Spring of 1940, he received the letter that has been the starting-point for this article, and which contained the announcement that Kunst was coming to Java. On 24 April 1940, the Prince replied to be delighted to be able to collaborate with him again 'in the interest of Javanese music, which is so close to both our hearts'. But the Prince was aware that the situation was unfavourable: 'Now we can only hope that events in Europe will not take such a turn as to make your departure to Java impossible.'

His hope turned out to be in vain. The journey was no longer possible: time and war had overtaken their plans. The Mangkunegoro must have been very sorry that his anxious suspicions were confirmed. He had already lost many friends. In the last years of his life he had to make do with memories of a richer and more hopeful time, a time when his palace was the focal point of discussion, exchange of ideas and meetings with like-minded people.

Jaap Kunst's two-part standard work, De toonkunst van Java (The Hague, 1934) (published in English in 1949 as Music ofJava), is a piece of tangible 
evidence from those days and of his very fruitful collaboration with the Mangkunegoro. The dedication at the front of the book speaks volumes: 'in respectful esteem and gratitude' to Mangkunegoro VII for his indispensable support for Kunst's research over fourteen years:

Despite the many worries and concerns which are part of the life of a selfruler, [he has] nevertheless taken the trouble [...] to critically read through the paragraphs relating to Java and, relying on his own considerable knowledge of Javanese music and that of his nyogos, has provided corrections and notes in the margin.

\section{References}

\section{Bibliography}

Brinkgreve, Clara. Met Indië verbonden, een verhaal van vier generaties, 1848-1949. Zutphen: Walburg Pers, 2009.

Djajadiningrat-Nieuwenhuis, Madelon. 'Noto Soeroto, his ideas and the late colonial intellectual climate', Indonesia, 55: 41-73, 1993. . Vorst tussen twee werelden. Schoorl: Conserve, 2006.

Djåwå. 'Beraadslagingen van de ontwikkelingsmogelijkheden van de muziek op Java', Djåwå 1-4: 284-300. [Three-monthly journal of the Java Institute.] 1921.

—. Djåwå. [Extra-nummer, aangeboden aan Mangkoenegoro VII.] 1924.

Huizinga, Johan. Herfsttij der Middeleeuwen: studie over levens- en gedachtenvormen der veertiende en vijftiende eeuw in Frankrijk en de Nederlanden. Haarlem: H.D. Tjeenk Willink, 1919.

Kunst, Jaap. 'Schrijven naar aanleiding der gestelde vragen', Djåwå 1-4: 123-125, 1921.

—. De toonkunst van Java. 's-Gravenhage: Nijhoff, 1934.

—. 'Proeve van een autobiografie' [Unpublished typescript.] 1959.

Kunst, J. with C.J.A. Kunst-van Wely. De toonkunst van Bali. Weltevreden: Kolff \& Co., 1925 .

Larson, George D. Prelude to revolution, palaces and politics in Surakarta, 1912-1942. Leiden: KITLV, 1987.

Proosdij-Ten Have, L.M. and M.J. van Roon. Jaap Kunst, correspondence 1920-1940: An annotated index. Amsterdam, The Netherlands: Van Proosdij/van Roon, 1992.

Roon, Marjolijn van. 'Jaap Kunst, government musicologist: An unusual incident in the colonial political history of the Netherlands East Indies', in: Wim van Zanten and Marjolijn van Roon (eds), Oideion 2: Special issue: Ethnomusicology in the Netherlands, pp. 63-83. Leiden: Centre of Non-Western Studies, Leiden University, 1995.

\section{Special Collections}

Kunst, Jaap. 'Correspondence 1920-1940'. University of Amsterdam, Special Collections, 1920-40.

Privécorrespondentie Mangkunegoro VII. 'Privécorrespondentie van Mangkunegoro VII, samengesteld door Jaap Erkelens' (Private correspondence of Mangkunegoro VII, as compiled by Jaap Erkelens). Archief Astana Mangkunegaran, Solo, n.d. 